\title{
Private Tutoring Across the Mediterranean
}

\section{Power Dynamics and Implications for Learning and Equity}

Mark Bray, André E. Mazawi and Ronald G. Sultana (Eds.)

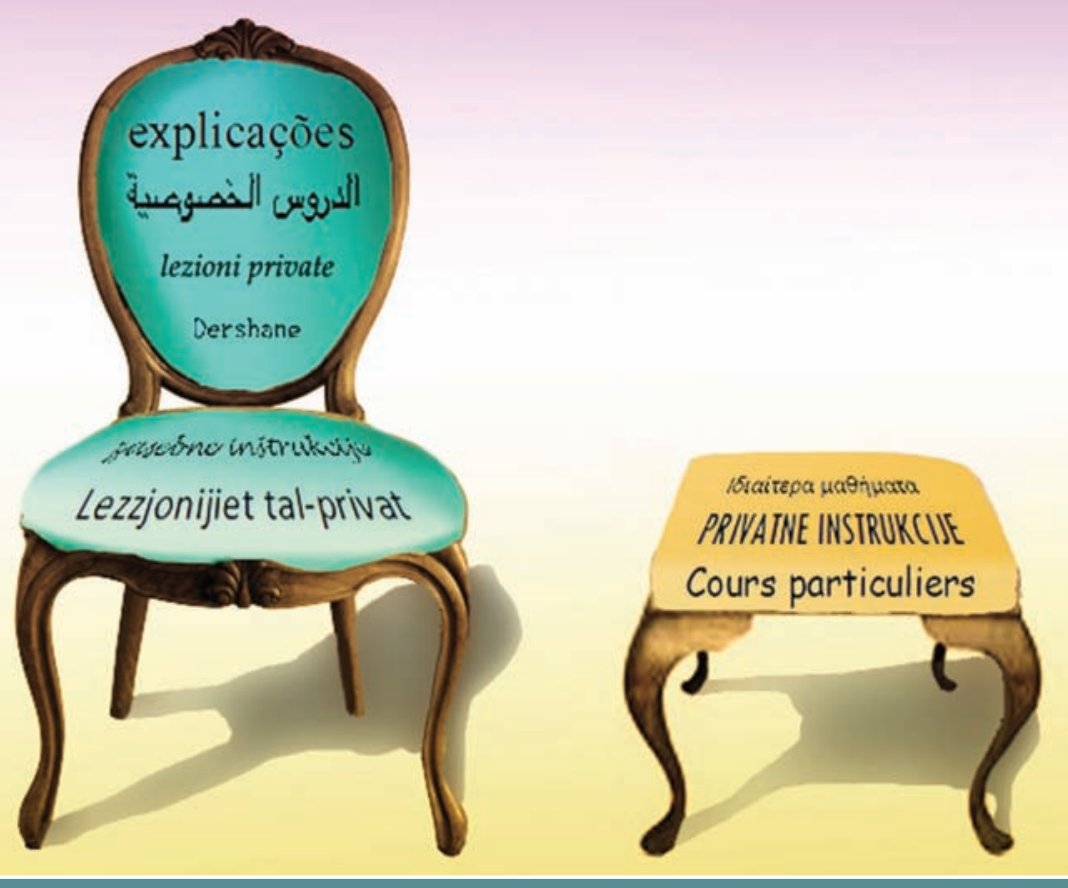

SensePublishers 
PRIVATE TUTORING ACROSS THE MEDITERRANEAN 


\section{COMPARATIVE AND INTERNATIONAL EDUCATION:}

\section{A Diversity of Voices}

Volume 25

\section{Series Editors}

Allan Pitman

University of Western Ontario, Canada

Vandra Masemann

University of Toronto, Canada

Miguel A. Pereyra

University of Granada

\section{Editorial Board}

Mark Bray, University of Hong Kong, Hong Kong PRC

Ali Abdi, University of Alberta, Canada

Christina Fox, University of Wollongong, Australia

Steven Klees, University of Maryland, USA

Nagwa Megahed, Ain Shams University, Egypt

Crain Soudien, University of Cape Town, South Africa

David Turner, University of Glamorgan, England

Medardo Tapia Uribe, Universidad Nacional Autónoma de Mexico

\section{Scope}

Comparative and International Education: A Diversity of Voices aims to provide a comprehensive range of titles, making available to readers work from across the comparative and international education research community. Authors will represent as broad a range of voices as possible, from geographic, cultural and ideological standpoints. The editors are making a conscious effort to disseminate the work of newer scholars as well as that of well-established writers.

The series includes authored books and edited works focusing upon current issues and controversies in a field that is undergoing changes as profound as the geopolitical and economic forces that are reshaping our worlds.

The series aims to provide books which present new work, in which the range of methodologies associated with comparative education and inter-national education are both exemplified and opened up for debate. As the series develops, it is intended that new writers from settings and locations not frequently part of the English language discourse will find a place in the list. 


\section{Private Tutoring Across the Mediterranean}

Power Dynamics and Implications for

Learning and Equity

Edited by

Mark Bray

University of Hong Kong, China

André E. Mazawi

University of British Columbia, Canada

and

Ronald G. Sultana

University of Malta, Malta

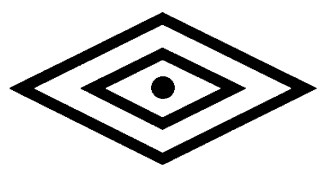


A C.I.P. record for this book is available from the Library of Congress.

ISBN 978-94-6209-235-8 (paperback)

ISBN 978-94-6209-236-5 (hardback)

ISBN 978-94-6209-237-2 (e-book)

Published by: Sense Publishers,

P.O. Box 21858, 3001 AW Rotterdam, The Netherlands

https://www.sensepublishers.com/

Printed on acid-free paper

All rights reserved $\odot 2013$ Sense Publishers and Mediterranean Journal of Educational Studies

No part of this work may be reproduced, stored in a retrieval system, or transmitted in any form or by any means, electronic, mechanical, photocopying, microfilming, recording or otherwise, without written permission from the Publisher, with the exception of any material supplied specifically for the purpose of being entered and executed on a computer system, for exclusive use by the purchaser of the work. 


\section{CONTENTS}

Chapter 1: Introduction: Situating Private Tutoring

Mark Bray, André E. Mazawi \& Ronald G. Sultana

Chapter 2: Private Tutoring and Social Equity in Croatia and Bosnia \& Herzegovina: A Comparative Qualitative Study

Boris Jokić, Andrea Soldo \& Zrinka Ristić Dedić

Chapter 3: Charting Private Tutoring in Cyprus: A Socio-Demographic Perspective

Iasonas Lamprianou \& Thekla Afantiti Lamprianou

Chapter 4: Education 'Home Delivery' in Egypt: Private Tutoring and Social Stratification

Sarah Hartmann

Chapter 5: Education as a Market in France: Forms and Stakes of Private Tutoring

Anne-Claudine Oller \& Dominique Glasman

Chapter 6: Shadow Education in Greece: Characteristics, Consequences and Eradication Efforts

Michael Kassotakis \& Athanasios Verdis

Chapter 7: Private Tutoring in Italy: Shadow Education in a Changing

Context

Giovanna Campani

Chapter 8: The Private Tuition Phenomenon in Malta: Moving toward a Fairer Education System

Michael A. Buhagiar \& Deborah A. Chetcuti

Chapter 9: Private Tutoring in Portugal: Patterns and Impact at Different Levels of Education

António Neto-Mendes, Jorge Adelino Costa, Alexandre Ventura,

Sara Azevedo \& Andreia Gouveia

Chapter 10: Constructions of Private Tutoring in Slovenian Online

Chatrooms: A Content Analysis

Armand Faganel \& Anita Trnavčevič 
TABLE OF CONTENTS

Chapter 11: Private Tutoring and Inequitable Opportunities in Turkey: Challenges and Policy Implications Aysit Tansel

Chapter 12: The Demand for Private Tutoring in Turkey: Unintended Consequences of Curriculum Reform Hülya Koşar Altinyelken

Chapter 13: Beyond Shadows: Equity, Diversity, and Private Tutoring 205 André E. Mazawi, Ronald G. Sultana \& Mark Bray

About the Authors 


\title{
MARK BRAY, ANDRÉ E. MAZAWI \& RONALD G. SULTANA
}

\section{INTRODUCTION}

\author{
Situating Private Tutoring
}

\begin{abstract}
Although private tutoring has a long history, prior to the present century it attracted very little professional discussion or academic research. Ministries of Education preferred and were allowed to ignore the phenomenon, chiefly on the grounds that tutoring was provided in a marketplace beyond their remit as supervisors of formal schooling. Faculties of Education in universities showed little interest, since their primary responsibilities were also with formal school systems. Likewise, international agencies mainly busied themselves with activities that focused on schooling. They paid little attention to out-of-school tutoring even though in some countries it was a major activity. Relegated to the 'private' sphere, as its name indicates, private tutoring has often been perceived by educators and policy makers as falling outside the purview of 'public' education and its equitable provision.

This inattention has begun to be remedied, as witnessed by the growing body of research on privatisation in education, which unsettles notions of what counts as 'private' and what counts as 'public' in the provision of schooling opportunities. This body of research shows not only that private tutoring is not a 'private' phenomenon, but that it is intertwined in complex ways with the public provision of schooling and operates in relation to it in multifaceted ways. Notwithstanding, huge gaps remain in both basic information and conceptual analysis. This collection addresses these gaps as they concern the Mediterranean region.

The first wide-ranging international study of private supplementary tutoring was published in 1999 by UNESCO's International Institute for Educational Planning (IIEP) (Bray, 1999). The book attracted considerable attention, but a common reaction was that it was mostly relevant to societies in East Asia, such as Hong Kong, Japan, South Korea and Taiwan, in which the phenomenon was especially visible. Although the book presented examples from all other regions of the world, general recognition of the phenomenon was weaker outside East Asia.
\end{abstract}

A decade later, however, a sequel (Bray, 2009) received much stronger recognition across the globe. This was partly because of the spread of private tutoring in all world regions, but also reflected expanded research which brought greater clarity to our understanding of the scale and implications of the phenomenon. This research showed that private tutoring takes different forms and is provided through a range of vehicles. Patricia Burch (2009) referred to 'hidden markets' in countries like the United States, where private tutoring witnessed the 'increasing activity of large corporate firms paired with controls on government' (p. 75). 
Burch's vocabulary echoed work on the 'hidden marketplace' in Eastern Europe and Central Asia (Silova, Būdienè, \& Bray, 2006), and the research complemented other work in Africa, Western Europe and elsewhere (e.g. Buchmann, 2002; Ireson, 2004; Lee, Park, \& Lee, 2009). In sum, by the end of the decade private tutoring had become recognized as a world-wide phenomenon that transcended geographic and national boundaries, as well as social class boundaries, with both policy makers and researchers beginning to look at the phenomenon more closely.

Private supplementary tutoring is widely called 'shadow education' on the grounds that much of its scale and shape is determined by mainstream schooling (Stevenson \& Baker, 1992; Bray, 1999; Lee, Park, \& Lee, 2009). Stevenson and Baker (1992) referred to shadow education as 'a set of educational activities outside formal schooling that are designed to improve a student's chances of successfully moving through the allocation process' within school (p. 1640). They suggested that the expansion of shadow education operated in relation to processes of allocation and mobility of students occurring within the formal school system, or in relation to their transition from high school to university. As a result, the 'content and existence [of shadow education] is tightly coupled to the organisation of transitions both within schooling and from school to the workplace' (p. 1655). As the curriculum in the mainstream changes, so it does in the shadow; and as the size of the mainstream grows, so does the size of the shadow.

Private tutoring is deeply rooted not only in the dynamics of economic markets (Dang \& Rogers, 2008), but also more broadly in cultural politics (Heyneman, 2011), parental competitive strategies (Aurini, 2008), and in subtle social class and gender relations (Safarzyńska, 2013). Hence, the study of private tutoring calls for sustained analytical and empirical efforts. It requires the deconstruction of the multifaceted implications of educational policy, economic markets, power politics, and cultural values, in ways that generate insights into the deployment of educational provision in various contexts. Equally, it requires an exploration of the local, regional, national, and global articulations of private tutoring in ways that highlight the larger, and often less visible, tectonic underpinnings that ultimately frame the meanings of education in particular social contexts, and their implications for marginalisation and exclusion.

The issue of equity is central to the theme of this volume. If left to market forces, private tutoring is likely to maintain and exacerbate social inequalities since prosperous families are more easily able to invest in greater quantities and superior qualities of tutoring.

Private tutoring may also have implications for personal development and for pedagogy. It can contribute to long hours of study each day, leading to imbalance between academic and other sides of life among students, family members, and educators. And private tutoring may have a backwash on the regular schools, negatively influencing the ways in which teachers perform their work, how they engage their students in class, and how they interact with families, and the wider community.

The present collection should be seen in the context of this wider problematisation of private tutoring and the questions to which it gives rise. The 
collection offers a set of critical insights into the complex and contextually-situated articulations and imbrications of this phenomenon. These insights go far beyond the exclusive emphasis on the economic and allocative functions of schooling. They reveal a private tutoring that strongly intersects with historical, socio-cultural and political dimensions unfolding in societies and from which this phenomenon draws not only its meanings, but also its persisting power and its manifold institutional manifestations.

\section{THE MEDITERRANEAN AS AN ARENA FOR COMPARISON}

The collection has a regional focus, namely the Mediterranean broadly defined. It may be compared with similar collections in other regions, some of which overlap. For example, many of the countries bordering the northern shores of the Mediterranean are part of the European Union (EU) and were examined in the study prepared by Bray (2011). Similarly, many of the countries bordering the southern shores of the Mediterranean are part of the Arab 'world' and were touched on by Mazawi and Sultana (2010, pp. 6-10). Other regional accounts have focused on sub-Saharan Africa (Bray \& Suso, 2008), Eastern Europe (Silova, Būdienė \& Bray, 2006), Central Asia (Silova, 2009), and Asia as a whole (Bray \& Lykins, 2012).

Focus on the Mediterranean as the region for analysis fits the core objectives of the Mediterranean Journal of Educational Studies (MJES), which is a partner with Sense Publishers in producing this work. As explained by Ronald G. Sultana (2009), the MJES is part of a mission to 'develo[p] a Mediterranean comparative education dimension' (p. 14). For Sultana, this mission is not about 'the search for epistemological and positivist purity in comparing 'like with like', It is rather about 'finding a new standpoint - one among many others ...- from where to gaze at phenomena and to apprehend it in new ways, by refracting it through a different lens' (p. 17). Thus, the 'legitimacy' that drives this collection, as a collaborative project of a community of scholars and researchers, is part of an agenda that seeks to transcend what Sultana (2009, p. 21) describes as 'dislocated provincialism', that 'insensitivity to context' which prevents the generation of an 'embedded' epistemology. In the present collection, this 'legitimacy' is expressed, in the words of Sultana (2009), through an effort to:

acknowledge the specificities of country and region - such as, for instance, the preponderance of informal labour markets and the impact this has on motivation to engage with formal learning; the negative returns to schooling; the importance of 'wasta' and family influence in getting employment; the particular relationship between religious elites and leaders in the state apparatus, and how this impacts on education in such areas as curriculum development; or the way private tutoring reproduces élites. (p. 22)

Over this backdrop, the present collection sets out to document and deconstruct the phenomenon of private tutoring across the Mediterranean. The point of departure is that private tutoring is a multifaceted and contested terrain. It offers an opportunity 
to explore a set of situated and sensitive social, political and policy questions, often distinctive to particular societies, their social and economic histories, and their 'imagined' political community. This distinctive feature of the collection is significant, since it drives the particular questions within each paper. The themes discussed by the contributors offer a wide set of perspectives on current educational debates in various Mediterranean countries. Some debates thematically converge across contexts, highlighting the relations between educational policies and questions of equality, equity, and social justice. Other debates provide vivid evidence that local or national constructions of private tutoring are historically situated, whether in relation to processes of state formation, political transitions, civic upheavals and wars, or in relation to local resonances of globalisation.

Approached from this perspective, studying private tutoring across the Mediterranean region offers a fertile terrain for a reflection on larger social, economic, and political issues associated with globalisation. It also touches on core questions of affiliation, social cohesion, citizenship, social stratification, and the role of the state, and more particularly of educational policies and school practices, in articulating the purposes of education and schooling in contemporary Mediterranean societies. It offers a unique opportunity to reflect on the continued reconfiguration of nation-states across the region, particularly since World War II (and in some cases earlier). The study of private tutoring inevitably touches on haunting and daunting questions around the formation of the contemporary nationstate in the Mediterranean region, and the class and identity politics prevalent in the societies that inhabit it.

The Mediterranean contains sub-regions with significant commonalities (such as within the Maghreb, and, more widely, all of the North African Arabic-speaking countries) while at the same time exhibiting great diversity (especially between the northern shores and southern shores, but also between west and east). In this book, individual chapters follow each other in country-alphabetical order, focusing on Bosnia \& Herzegovina, Croatia, Cyprus, Egypt, France, Greece, Italy, Malta, Portugal, Slovenia, and Turkey. This collection results from both responses to a general call for papers and active search for authors. The outcome is a set of chapters that reflects the considerable diversity of cultures, economies and educational traditions in the Mediterranean region.

At the same time, it is worth noting the countries which are not specifically included. Among them are Albania, Algeria, Israel, Jordan, Lebanon, Libya, Morocco, Palestine, Syria, Spain and Tunisia. The absence of commentaries from these locations reflects the paucity of research on private tutoring in contexts which nevertheless experience the phenomenon on a wide scale. The desirability of securing data from countries in which so far no research on this topic has been conducted is among the matters deserving further attention - a point repeated in the last chapter which maps a future research agenda.

Meanwhile, to provide a lens through which readers may view the chapters which follow, it is useful to make some further remarks on the units for comparison. The above pair of paragraphs privileges the country as the principal unit. It creates some conceptual questions since all the countries have non- 
Mediterranean borders as well as Mediterranean ones. Thus France, for example, has an Atlantic coast as well as a Mediterranean one, and Algeria has a border in the Sahara desert. Nevertheless, focus on countries as the principal unit for analysis has a long tradition in the field of comparative education (see e.g. Bereday, 1964; Postlethwaite, 1988; Manzon, 2007). It has pertinence insofar as education systems are still strongly shaped by the policies of national governments. Despite the intensification of globalisation and other cross-border forces, national education systems remain differentiated from each other; and when national systems differ, so do their shadows.

At the same time, the book has many other units of analysis. At one end of a spectrum, Hartmann's chapter on Egypt includes focus on individual students and teachers. The chapter on Portugal by Neto Mendes, Costa, Ventura, Azevedo and Gouveia describes research in the Xplika project which compared patterns in schools and between grades in those schools. In this respect, the set of chapters could be mapped on the cube presented by Bray and Thomas (1995) which highlighted a hierarchical range of units for analysis nested within each other. Part of the cube's usefulness lies in its demonstration of relationships, and particularly the importance of contextual factors at higher levels. Thus cultural factors at the supranational level may shape features within particular countries, which may in turn shape features in provinces or districts, and the schools, classrooms and individuals, and vice versa. For the present collection of chapters, there are grounds to consider shadow education in the Arabic-speaking countries in the southern Mediterranean as having some features in common, and for countries in the northern Mediterranean having other features in common. The importance of context has been constantly underlined by comparative educationists (see e.g. Crossley \& Jarvis, 2001) and should be borne in mind when reading each chapter in this book.

\section{METAPHORS AND TERMINOLOGY}

The contributions in the present collection are important for two inter-related reasons. In settings in which very little has been written on private tutoring, the contributions reduce the gap in basic data. They also extend the conceptual analysis of the phenomenon beyond questions of formal schooling, thus presenting new perspectives. Taken individually the contributions provide information and analysis on shadow education in specific countries; and taken as a group they provide an instructive array for comparative analysis across the Mediterranean region.

The metaphor of 'shadow education' is used by several contributors. In some circumstances, shadows might have a negative connotation. At the outset it is therefore useful to note different dimensions of terminology. This Introduction has already used the term 'private tutoring' multiple times. A common alternative, used for example in the chapter on Malta by Buhagiar and Chetcuti, is private tuition. These terms may be taken as interchangeable. The term private tuition is also used in other countries, such as Mauritius (see e.g. Foondun, 2002) and Pakistan (see e.g. Aslam \& Mansoor, 2012), though it is less commonly used in North America where the word tuition is commonly used to refer to school fees, and thus has a 
different meaning. Rather than either private tutoring or private tuition, the common term in North America is supplemental education (see e.g. Heinrich, Meyer, \& Whitton, 2010; Mori \& Baker, 2010).

In addition, the chapters on Egypt, Italy and Malta refer to private lessons (durus khususiyya in Arabic, lezioni private in Italian, privat or lezzjonijiet talprivat in Maltese). This terminology implies close mimicry of regular lessons in the private sector, whereas supplemental education may imply that pupils receive additional elements that they would not have received in the regular lessons. The notion of mimicry is also evident in the Greek word parapedia, which literally means parallel education. Perhaps it is not accidental that this Greek terminology does not refer to supplementation since that word would imply something optional whereas in Greece the additional classes have in effect become obligatory for all families that can possibly afford them.

Going further, the chapter on France identifies three different types of activity labelled private lessons (cours privés), after-school support (soutien scolaire), and coaching (which has become a French term, adopted from English, as coaching scolaire). In this usage, private lessons focus exclusively on academic curricular subjects; after-school support focuses on completion of homework and activities intended to broaden children's minds, widen their vocabulary, boost their cultural references, and improve such skills as cooperation, observation and questioning of things they observe; and coaching aims at study processes rather than study content, helping students to define their academic and professional goals through one-to-one support similar to coaching in sporting activities.

These elements of vocabulary are stressed at the outset not only to allow readers to interpret and compare the individual chapters but also to highlight a number of complexities and ambiguities - linguistic, yet also historical, cultural and institutional. Although this book is written in English, only in Malta is English an official language - and even in that country, English shares space with Maltese as the other official language. Thus the book relies on translations of words which may have nuances in their original languages that are lost when translated into English. Equally, the same word may have different meanings when used in different locations. Thus, while 'coaching' in France has been used for analogy in the educational sphere to its usage in sports and particularly on a one-to-one basis, in India 'coaching' tends to refer to larger groups and parallel academic courses (see e.g. Sujatha \& Rani, 2011). Again, shadow education implies mimicry, but the edges of shadows are commonly blurred and may have overlaps with educational practices which supplement rather than just repeat the content of regular classes. Further comments will be made on these matters in the final chapter, which highlights some of the practical and conceptual lessons that may be drawn from the set of country studies.

\section{DIFFERENT ANGLES OF APPROACH}

The individual chapters display considerable diversity in their approaches to the study of private tutoring. Giovanna Campani's chapter on Italy has a strong 
historical emphasis beginning in the $19^{\text {th }}$ century. This chapter highlights the impact of major political tides that have shaped the structures of power underpinning the Italian state on the roles and meanings of private tutoring. Campani shows how under distinct political circumstances private tutoring operated as a venue for political resistance, more recently becoming strongly involved in the reproduction of social class inequalities.

In their chapter on Greece, Michael Kassotakis and Athanasios Verdis also commence with an instructive historical section. They discuss the impacts of the Greek-Turkish war of 1919-1922, the Greek Civil War of 1946-1949, and the dictatorship of 1967-1974 on the emergence of different types of private tutoring, and their deployment in different geographic regions. This chapter outlines the power struggles over private tutoring prevalent in Greece, and their implications for regional disparities in educational and social opportunities and for psychological pressures on students in their transition to higher education.

With reference to France, Anne-Claudine Oller and Dominique Glasman observe that tutoring can be a way for some learners to keep up with their peers and to gain access to understandings of curriculum content which were not achieved during regular classes. Tutoring is a structured activity for young people who might otherwise not be so focused; and some parents invest in private tutoring as a way to alleviate the stresses of homework supervision. Oller and Glasman point out that the most common and recurring arguments between parents and their children are based on schoolwork, and that employment of private tutors can be a way to reduce tensions. At the same time, state policies, which indirectly subsidize families' payments to tutoring corporations, raise core questions regarding the roles of markets in determining equity in social opportunities and access to educational resources.

The chapter by Boris Jokić, Andrea Soldo and Zrinka Ristić Dedić has a related approach insofar as it is also couched within a framework of political history and the interactions of economic and social forces. This chapter compares two countries which emerged following the break-up of Yugoslavia in the 1990s, namely Croatia and Bosnia \& Herzegovina. It is especially insightful in its systematic juxtaposition of patterns in this pair of countries on a Bereday-type model (see Bereday, 1964). The data are derived from semi-structured interviews and focus groups in a conscious effort to build on earlier methodological approaches for the study of private tutoring (Silova, Būdienè, \& Bray, 2006).

The Slovenian chapter by Armand Faganel and Anita Trnavčevič, by contrast, is based entirely on internet search. It examines pricing structures and modes of operation of tutoring providers, and analyzes online chatrooms to see what sorts of issues are raised and how. Thematic aspects include value for money, parental help, tutors' reputations, the links between tutoring and regular teaching in schools, and the modalities of tutoring. At the same time, the chapter matches others in the volume in the way that it is framed by awareness of economic and social change in Slovenia. And since Slovenia also emerged in 1991 from the collapse of Yugoslavia, significant parallels exist between this chapter and the one on Croatia and Bosnia \& Herzegovina. 
Two chapters in the collection focus on Turkey. The first is by Aysit Tansel, who is already well known in the English-language literature through her statistical analyses of various dimensions of tutoring in Turkey (e.g. Tansel \& Bircan, 2006, 2008). This new contribution focuses more on political and organisational dimensions. It has especially instructive remarks about the Association for Private Tutoring Centres, Os-De-Bir, which was established in 1985 and which plays a significant role in the lives of students and their families by running mock examinations on a national basis. This indeed is a shadow of a different magnitude, not just at the level of an individual tutor aligning with the school curriculum but in a whole apparatus for assessment at the national level. Tansel also has remarks about the extent to which tutoring is sought by students in different curriculum streams, thereby adding a further strand for comparison.

The second chapter on Turkey, by Hülya Koşar Altinyelken, focuses on matters of curriculum. It serves as a timely reminder that reform implementation efforts can have consequences that are not only unintended but which are actually the opposite of the aspired outcome. In the case of Turkey, and despite strong government commitment to moderate if not eradicate private tutoring, the introduction of a new competence-based curriculum increased rather than decreased the recourse to private tuition. The new curriculum emphasized process rather than coverage, and was perceived by many - including parents and teachers - as a dilution of the content of the programmes taught at school. This led to feelings of insecurity, given that the traditional examinations had not been aligned with the curriculum initiative, and as a consequence the perception that regular schooling was not enough to guarantee educational success became even more trenchant.

The chapter on Cyprus by Iasonas Lamprianou and Thekla Afantiti Lamprianou provides an important insight on the strategies of the state in its attempts to control the private tutoring industry. By providing 'private' tutoring at reduced fees, the Cypriot education authorities attempted to drive private, for-profit providers out of the market. Not only did this strategy ultimately fail, but it also reinforced the general perception that regular schooling was not sufficient to ensure educational success, and that supplementing it with after-school instruction was not only legitimate, but advisable. Widespread tutoring provision through three types of institutions - namely the privately owned, the state controlled, and illegal entities operating underground - means that in Cyprus, unlike some other countries represented in this volume, access to private tuition is also open for students from lower socio-economic backgrounds. However, differences in access to quality provision are bound to remain.

The above remarks are just a few highlights from this rich collection of papers. Readers are invited to savour the insights from each individual chapter, following which the final chapter in this book presents a further analytical overview. 


\section{REFERENCES}

Aslam, M., \& Mansoor, S. (2012). The private tuition industry in Pakistan: An alarming trend. Policy Brief. Islamabad: South Asia Forum for Education Development.

Aurini, J. (2008). Understanding the private tutoring revolution in Canada. Our Schools, Our Selves, 17(3), 93-105.

Bereday, G. Z. F. (1964). Comparative method in education. New York: Holt, Rinehart \& Winston.

Bray, M. (1999). The shadow education system: Private tutoring and its implications for planners. Paris: UNESCO International Institute for Educational Planning (IIEP).

Bray, M. (2009). Confronting the shadow education system: What government policies for what private tutoring? Paris: UNESCO International Institute for Educational Planning (IIEP).

Bray, M. (2011). The challenge of shadow education: Private tutoring and its implications for policy makers in the European Union. Brussels: European Commission.

Bray, M., \& Lykins, C. (2012). Shadow education: Private supplementary tutoring and its implications for policy makers in Asia. Manila: Asian Development Bank, and Hong Kong: Comparative Education Research Centre, The University of Hong Kong.

Bray, M., \& Suso, E. (2008). The challenges of private supplementary private tutoring: Global patterns and their implications for Africa. Paper for the Biennale of the Association for the Development of Education in Africa, Maputo, Mozambique.

Bray, M., \& Thomas, R. M. (1995). Levels of comparison in educational studies: Different insights from different literatures and the value of multilevel analyses. Harvard Education Review, 65(3), 472-490.

Buchmann, C. (2002). Getting ahead in Kenya: social capital, shadow education, and achievement. In B. Fuller \& E. Hannum (eds) Schooling and Social Capital in Diverse Cultures. Amsterdam: JAI Press, pp.133-159.

Burch, P. (2009). Hidden markets: The new education privatization. London: Routledge.

Crossley, M., \& Jarvis, P. (2001). Context matters. Comparative Education, 37(4), 405-408.

Dang, H.-A., \& Rogers, H. (2008). The growing phenomenon of private tutoring: Does it deepen human capital, widen inequalities, or waste resources? The World Bank Research Observer, 23(2), 161-200.

Foondun, A. R. (2002). The issue of private tuition: An analysis of the practice in Mauritius and selected south-east Asian countries. International Review of Education, 48(6), 485-515.

Heinrich, C. J., Meyer, R. H., \& Whitton. G. (2010). Supplemental services under No Child Left Behind: who signs up, and what do they gain? Educational Policy and Analysis Archives, 32(2), 273-298.

Heyneman, S. P. (2011). Private tutoring and social cohesion. Peabody Journal of Education, 86, 183188.

Ireson, J. (2004). Private tutoring: How prevalent and effective is it? London Review of Education, 2(2), 109-122.

Lee, C. J., Park, H. J., \& Lee, H. (2009). Shadow education systems. In G. Sykes, B. Schneider, \& D. N. Plank (Eds.), Handbook of education policy research (pp. 901-919). New York: Routledge for the American Educational Research Association.

Manzon, M. (2007). Comparing places. In M. Bray, B. Adamson, \& M. Mason (Eds.), Comparative education research: Approaches and methods (pp. 85-121). Hong Kong: Comparative Education Research Centre, The University of Hong Kong, and Dordrecht: Springer.

Mazawi, A. E., \& Sultana, R. G. (Eds.). (2010). Education and the Arab 'world': Political projects, struggles, and geometries of power. London: Routledge.

Mori, I., \& Baker, D. (2010). The origin of universal shadow education: What the supplemental education phenomenon tells us about the postmodern institution of education. Asia Pacific Education Review, 11(1), 36-48.

Postlethwaite, T. N. (Ed.). (1988). The encyclopedia of comparative education and national systems of education. Oxford: Pergamon Press.

Safarzyńska, K. (2013). Socio-economic determinants of demand for private tutoring, European Sociological Review, 29(2), 139-154. 
Silova, I. (Ed.). (2009). Private supplementary tutoring in Central Asia: New opportunities and burdens. Paris: UNESCO International Institute for Educational Planning (IIEP).

Silova, I. (2010). Private tutoring in Eastern Europe and Central Asia: Policy choices and implications. Compare: A Journal of Comparative and International Education, 40(3), 327-344.

Silova, I., Būdienė, V., \& Bray, M. (Eds.). (2006). Education in hidden marketplace: Monitoring of private tutoring (pp. 71-98). New York: Open Society Institute.

Stevenson, D. L., \& Baker, D. P. (1992). Shadow education and allocation in formal schooling: transition to university in Japan. American Journal of Sociology, 97(6), 1639-1657.

Sultana, R. G. (2009). Looking back before moving forward: Building on 15 years of comparative educational research in the Mediterranean. In C. Borg, P. Mayo, \& R. G. Sultana (Eds.), Mediterranean studies in comparative education (pp. 9-25). Malta: Euro-Mediterranean Centre for Educational Research, University of Malta.

Sujatha, K., \& Rani, P. G. (2011). Management of secondary education in India. New Delhi: Shipra and National University of Educational Planning and Administration (NUEPA).

Tansel, A., \& Bircan, F. (2006). Demand for education in Turkey: A Tobit analysis of private tutoring expenditures. Economics of Education Review, 25(3), 303-313.

Tansel, A., \& Bircan, F. (2008). Private supplementary tutoring in Turkey: Recent evidence on its various aspects. Discussion Paper No. 3471. Bonn: Institute for the Study of Labor (IZA). 


\title{
2. PRIVATE TUTORING AND SOCIAL EQUITY IN CROATIA AND BOSNIA \& HERZEGOVINA
}

\author{
A Comparative Qualitative Study
}

\begin{abstract}
Empirical evidence from various social and educational contexts suggests that private tutoring (PT) services are more accessible to pupils from families of more advantaged socio-economic status. This, in turn, reflects and/or exacerbates both social and educational inequalities, an outcome that has been shown through previous research in Croatia and Bosnia \& Herzegovina. The present chapter explores educational stakeholders' perspectives on the differences in patterns of PT use by pupils from different socio-economic backgrounds. Secondly, it explores the relevance educational stakeholders assign to the issue of social equity related to PT and their willingness and capacity to address this issue. Data were collected using individual semi-structured interviews and focus groups with selected educational stakeholders. Criterion and purposive sampling were used to identify educational stakeholders from governmental, political, professional, parental, educational, media and academic spheres. The findings indicate that, in both countries, social equity issues associated with PT are mainly related to differences in the quality, frequency, continuity and purpose of PT services. Issues of social equity, as they relate to PT, emerged as a marginal concern. In addition, the findings from both countries indicate a lack of readiness and ability amongst educational stakeholders to adequately deal with and address issues of social equity. The findings also revealed a substantial homogeneity of perspectives between and within the two countries.
\end{abstract}

\section{INTRODUCTION}

Research in a number of social and educational contexts has shown that private tutoring (PT) services are more accessible to pupils from families of more advantaged socio-economic status. This, in turn, reflects and/or exacerbates both social and educational inequalities (Bray, 1999; Jung \& Lee, 2010; Kim, 2007; Kwok, 2004; Scanlon \& Buckingham, 2004; Schneider, 2006; Silova, 2010; Silova, Būdienè, \& Bray, 2006). This fact has also been clearly demonstrated in empirical findings from Bosnia \& Herzegovina and Croatia (Husremović \& Trbić, 
2006; Ristić Dedić, Jokić, \& Jurko, 2006). Indeed, this negative consequence for social equity is often cited as one of the most common implications of PT (Bray, 2009). Using a qualitative methodology, this paper explores the perspectives of educational stakeholders concerning social equity issues associated with PT in Croatia and Bosnia \& Herzegovina. ${ }^{1}$

\section{PRIVATE TUTORING IN CROATIA AND BOSNIA \& HERZEGOVINA}

Despite a long history of PT dating back to the days of Yugoslavian socialism, no systematically collected data examining PT in Croatia and Bosnia \& Herzegovina exists prior to the 2006 'Monitoring of Private Tutoring' project (Silova, Būdiene \& Bray, 2006). This large scale quantitative project was undertaken among secondary education pupils and university students. Findings indicated that PT was widespread in both countries, with over half of the pupils reporting use of PT services during their secondary education (Husremović \& Trbić, 2006; Jokić \& Ristić Dedić, 2007; Ristić Dedić, Jokić, \& Jurko, 2006). Most PT users reported taking private lessons occasionally, usually at the end of the semester or during testing periods. In both countries, pupils most commonly take lessons in Mathematics. The main function of PT is remedial, primarily to pass exams or to enter to the next school grade. The findings also indicated that teaching professionals, ranging from pre-service and unemployed teachers to university professors, are the main providers of PT. The most common method of finding a tutor was a reliance on informal recommendations in which a pupil's teacher or acquaintance recommends another teacher or an expert to provide the tutoring. In Croatia, there also exists a well-established market of organisations providing preparatory courses for final exams in secondary education or university entrance exams. This form of PT is still developing in Bosnia \& Herzegovina.

This first project provided some early insight into the issue of social equity and the use of PT. Significant positive correlations were found between PT services and pupils' self reported indicators of familial income and parental education level (Husremović \& Trbić, 2006, Ristić Dedić, Jokić, \& Jurko, 2006). Furthermore, pupils from high-income families where both parents held university degrees more frequently relied on PT lessons. While $65.4 \%$ of Croatian respondents and $56.9 \%$ of their Bosnia \& Herzegovina counterparts disagreed or strongly disagreed with the statement 'Only students from wealthy families can afford private tutoring', $70.7 \%$ of the respondents in Bosnia \& Herzegovina and $71.2 \%$ of counterparts in Croatia agreed or strongly agreed with the statement 'Students from wealthy families can hire better tutors'. These findings suggest that, while respondents recognise that $\mathrm{PT}$ is widespread, they are aware of the possibility that differences in the quality of services are related to social class distinctions among pupils.

The present paper relies on the data gained from this initial project as a starting point for a consideration of the relationship between PT and social equity issues in these contexts. Notwithstanding, the quantitative approach used in the initial project did not allow for a deeper investigation of these issues. Furthermore, the project's sole focus on students did not allow for the perspectives of other 
educational stakeholders to be represented. Arguably, the views of these stakeholders might contribute to a more complete understanding of the relationship between PT and social equity. As such, the collection of richer, descriptive data was deemed necessary in order to understand the ways in which the relationship between PT and social equity is perceived and understood by various stakeholders. This approach is consistent with arguments made by Gorard \& Taylor (2004) regarding the use of multiple methods when researching complex topics such as PT. Quantitative research should provide an answer to questions of 'what' and 'how many', whereas qualitative research should answer questions of 'how' and 'why'.

The aims of the present paper are twofold. First, the paper explores educational stakeholders' perspectives of PT use by pupils from different socio-economic backgrounds. Secondly, it aims to explore the relevance educational stakeholders assign to the issue of social equity related to PT and their willingness and capacity to address it.

Examining this topic in Croatia and Bosnia \& Herzegovina is of particular interest. The two countries shared their history as socialist republics within the former Yugoslavia. Yet, both experience specific challenges in their transition to market economies. To better appreciate the relevance of this specific context, a comparative description of both countries will be briefly considered.

\section{COMPARATIVE CONTEXT}

In the early 1990s, Croatia and Bosnia \& Herzegovina gained independence and became separate sovereign states. Both countries were involved in armed conflicts in order to gain statehood, resulting in significant human loss and population displacement. Following the cessation of war atrocities, both were engaged in postwar reconstruction and a transition moved from planned to market economies. Alongside a shared past, the social and economic development of each country following the break-up of Yugoslavia took somewhat different trajectories. In socialist Yugoslavia, Croatia was economically more established, with a GDP significantly higher than that of Bosnia \& Herzegovina (Jurčić \& Vojnić, 2010). Croatia underwent political and economic consolidation faster, achieving a GDP level in the early 2000s equivalent to that of the early 1990s. This is yet to be achieved in Bosnia \& Herzegovina (Jurčić \& Vojnić, 2010). In both countries, employment rates are amongst the lowest in Europe and the proportion of longterm unemployment is higher than in the majority of EU countries (World Bank, 2006; UNDP, 2009). Unemployment is particularly high in Bosnia \& Herzegovina, where estimates have ranged between $16 \%$ and $44 \%$, depending on the method for calculating unemployment rates (UNDP, 2009). There are significant differences between countries in poverty levels and social inequality in term of Gini's coefficient (where a value of 0 represents absolute equality and 100 represents maximum inequality). In comparison to other countries in transition, the level of poverty in Croatia, based on a cost-of-basic-needs poverty line, is reasonably low; approximately $11 \%$ of the population is poor, and another $10 \%$ is at risk of poverty 
(World Bank, 2006). In Bosnia \& Herzegovina, about one fifth of the population lives below the general poverty line. In addition, a third is poor in relative terms and at risk of falling below that line (UNDP, 2009). In 2008, Croatia had a Gini coefficient of 29, a value equivalent to most developed European countries. In 2007, Bosnia \& Herzegovina had a Gini index of 34.1, a value representative of considerable inequality in the society and significantly higher than that of Croatia.

The socialist legacy in both Croatia and Bosnia \& Herzegovina strongly emphasised the value and role of education in the life of the individual. Education was promoted and perceived as a way to ameliorate one's position in society. The experience of educational mobility was characteristic for a large number of families, even from the most economically disadvantaged regions (Klemenović \& Milutinović, 2002). One of the pillars of this position was the idea that education is a public good, free and available to all under equal terms (Klemenović \& Milutinović, 2003). Mass provision of socialist education fostered a sense of social cohesion within society, the consequences of which were nearly universal general education enrolments, high literacy rates, as well as a shared public belief in a freeof-charge education, provided on an egalitarian basis (Heyneman, 2000; Silova \& Bray, 2006).

Transition to market economies had a clear reflection in the field of education in both countries, particularly at the tertiary level of education with the establishment of many private universities and polytechnics and growth in student participation. Both primary and secondary levels of education have seen very limited development in private education ventures. Although legislation has allowed for the opening of private schools whose operation is partially state financed, only a small proportion of pupils are enrolled in these schools. Private schools have yet to build a reputation that would give them a competitive edge over the state system. It could be argued that the largest private enterprise in education has been through the provision of individual PT lessons and organised preparatory courses.

In addition to some of the positive features of the socialist educational system, both countries have retained some of the negative characteristics of the former system. A content oriented curriculum that is fragmented across disciplines and traditional teaching practices are still prevalent in both primary and secondary education (Baranović, 2006). Furthermore, the educational systems in both countries are characterised by a low level of harmonisation between different educational levels. Ristić Dedić and Jokić (2011) and Soldo (2011) argue that these characteristics are amongst the main factors driving the use of PT in these countries.

In Croatia, issues of social inequality in education have only recently come prominently into researchers' focus. Here, several large scale quantitative studies have indicated moderate to strong effects of socio-economic status on pupils' educational achievement, as expressed through PISA (Programme for International Student Assessment) results (Gregurović \& Kuti, 2010), the results of external assessment in elementary education (Babarović, Burušić, \& Šakić, 2009) and through pupils' achieved grades in elementary education (Jokić \& Ristić Dedić, 
2010). In Bosnia \& Herzegovina, there is still a lack of large-scale empirical data on social inequality in education.

\section{METHODOLOGY}

There have been numerous calls for more empirical research examining PT from diverse methodological approaches (e.g. Bray, 2003, 2011). In particular, there have been very few qualitative research endeavours probing this phenomenon. Comparative qualitative efforts are even less common, both in educational research generally and in PT research in particular. One of the aims of this paper is to address some of these methodological shortcomings in the field.

Individual semi-structured interviews and focus groups were conducted with selected educational stakeholders. This methodological choice was deemed appropriate due to the selected number of educational stakeholders, a need for a deeper understanding of stakeholders' perspectives, and an orientation towards the co-creation of appropriate policy options. The complexity of the topic, the variety of professional backgrounds of the interviewees, and a respect for their time were some of the factors that further justified the decision to use semi-structured interviews.

The participant selection process was coordinated in both countries in order to ensure adequate levels of comparability. Criterion and purposive sampling were used to identify educational stakeholders from governmental, political, professional, parental, educational, media and academic spheres. The inclusion of individuals and organisations from such varied contexts allowed for the gathering of a wide range of perspectives. The educational stakeholders included from both countries are listed in the Appendix.

The project had two rounds of interviewing. Based on the relevance of information provided in the first interview and their potential influence on policy change, a select number of participants were invited to participate in the second round of interviews. Procedures for initial stakeholder contact, in addition to negotiation and interview procedures, were agreed upon and coordinated in both countries. In addition, interview and focus group schedules were commonly developed by research teams in both countries. Some of the covered themes included: implicit constructions and understanding of the PT phenomenon; the level of awareness of the prevalence of PT; factors driving PT demand and supply; implications of PT for the educational system, society and economy; suggestions for the regulation of PT; and the development of possible policy options. The issue of social equity related to PT was probed in both rounds of interviewing. Specifically, the focus was on respondents' awareness and assigned relevance of equity issues related to PT; perceived differences in accessibility, affordability, and quality of services as well as the function of PT for pupils from different backgrounds; implications for equality of opportunities in mainstream education; and perceived need for addressing this issue within educational policy.

In total, 46 individual interviews and six focus groups were conducted, recorded and transcribed, amounting to approximately 160 hours of recorded material. Data 
for both countries were collected in a common database and were subsequently analysed using the NVivo software. Analysis used a dual temporal coding approach in which some codes were pre-determined based on the conceptual framework of the project and interview schedules while other codes were developed in response to the collected data itself. In the first phase of coding, the issue of social equity was placed under the tree nodes Drivers of PT/Societal and Effects of PT/Societal. The rationale for this comes from the literature on PT and the initial PT project (Bray, 1999; Silova, Būdienè, \& Bray, 2006). In a second phase of coding, new codes examining social equity specifically were determined. Among others, this included codes for the accessibility and affordability of services, patterns of use, function of PT and implications for educational success of pupils from different backgrounds. Codes on respondents' assigned relevance to the issue and their willingness and capacity to deal with the issue were also determined.

\section{FINDINGS AND DISCUSSION}

\section{Accessibility and Affordability of PT Services for Pupils from Different Socio-Economic Backgrounds}

The initial PT study demonstrated that a majority of pupils in secondary education used PT services in Croatia and Bosnia \& Herzegovina. The omnipresence of the phenomenon was also evident in the observation that almost all interviewees in both countries reported having had personal experience with PT services either as users, providers or parents of pupils relying on PT. This all-encompassing scope of PT was further triangulated with qualitative data in both countries, which depicted a commonly held view that 'almost everyone' presently uses PT services, as evidenced by the following quote from the Bosnian dataset:

When I used to go to school only a few pupils took PT lessons, those were 'dumb ones', I mean so-called 'dumb ones'. Since then it [PT] just grows and now you have a situation that almost everyone takes lessons. (PT provider, $\mathrm{B} \& \mathrm{H})$

Undoubtedly, one of the elements contributing to the widespread reliance on PT is its affordability. Here, it seems that the diversity of providers and the variance in PT fees play a vital role, as evidenced in the following interview excerpt from a PT provider:

It is sad for me to say, but this is a cheap service. Even worse, you can get it for much less than what I am charging if you go to some university student.

A service that fits every pocket, I say. (PT provider, Croatia)

This quote suggests the existence of a competitive market among PT providers, implying a sufficient supply of service and diversity of providers. Arguably, the variance in fees results in a situation in which even those from underprivileged social backgrounds can afford some sort of PT service. However, when prompted 
about the issue of affordability of services to all pupils, interviewees' answers indicate that there are groups who cannot afford PT services. In both countries, elected students' representatives, representatives of teachers' unions and PT providers are the groups most aware of the inability of certain social groups' to afford services, as evidenced by these words from a pupil:

I see it in my own class. There are pupils who have problems with something and they would like to have PT lessons, but they cannot afford them, especially those [held] in pupils' homes. Definitely there are pupils who cannot afford this cost. (Elected students' representative, Croatia)

One PT service provider observed:

I really cannot believe that there are so many children now who need private lessons ... On the other hand, I am sure there are those who really need it but cannot afford it. (PT provider, B\&H)

Certainly, the inability of some groups to afford PT services has serious educational implications. Such implications are reflected in the poignant observation made by a mathematics teacher offering PT lessons:

I am ashamed to admit it but as teachers we do it all the time ... we recommend to children and parents to take PT lessons. The student is OK, but has a problem with a part of the curriculum. And then, it happened to me several times already, parents tell me they do not have money for that. What can I do? I can't give him a grade if he does not deserve it. At the same time, his peer from a wealthier family, takes lessons and gets a grade. (Teacher and individual PT provider, Croatia)

The above quote illustrates several interesting elements depicting the PT phenomenon in both contexts. First, it confirms the common practice of teachers to recommend PT services, already demonstrated in the initial study. Secondly, it explicitly demonstrates that teachers are themselves aware of the fact that educational achievement is directly related to the use of PT services. Thirdly, it suggests that people recognise that these services are not affordable for a certain number of pupils from underprivileged backgrounds, affecting their educational outcomes. Finally, and perhaps most worryingly, it indicates a lack of accountability and critical reflection on the role of teachers and the school in assuring pupils' successful completion of educational tasks.

On the whole, it seems that PT services are accessible and affordable to most pupils in both countries. Differences in economic indicators and development between the two countries notwithstanding, there are groups of pupils who cannot afford PT lessons, even in Croatia. It is plausible to expect that the well-developed market of PT services and the diversity of service fees will result in differing patterns and reasons for use of PT services, depending on the students' socioeconomic background. The relationship between different PT services to student background will be explored in the following section. 


\section{Versatility of PT Services for Pupils from Different Socio-Economic Backgrounds}

The data from both countries confirm Bray's (2011) notion that pupils from more privileged backgrounds use PT services more often. They are also in a position to hire more highly qualified tutors. A representative from the teachers' union in Bosnia \& Herzegovina captures this point:

The most frequent users are those pupils whose parents don't have time for them but have money. Those parents can get any tutor they want for however long. Poorer parents less frequently use PT, and mostly so that their children do not to lose the year. (Representative from the teachers' unions, B\&H)

A similar perspective is evident in the words of a school principal in Croatia:

Everyone takes lessons but in a different manner. I notice that children of lower social status also take PT, but only when they face a problem. Those of the higher status and especially those with more highly educated parents go more continuously and with a set goal. They go more frequently and go to better instructors, because they can afford them. (Principal, Croatia)

The above quotes suggest significant patterns of stratification in the use of PT by pupils from different social class backgrounds. They also capture the notion that these differences in the quantity and quality of PT use are a reflection of the purpose of PT use. Namely, the more planned and frequent use of PT by pupils from more advantaged socio-economic backgrounds, in combination with the ability to hire tutors of better quality, is suggestive of a subtler mechanism behind issues of social equity and PT use. Evidence from the interviews further suggests that pupils from families of more advantaged socio-economic status start using services earlier and over lengthier periods of time.

Both quotes also imply that parents of more advantaged socio-economic status approach PT as a planned activity, suggestive of a more strategic positioning in relation to PT. However, the use of PT as a highly-planned and direct form of enrichment is true for only a small number of families, a feature evidenced in this excerpt from a high official from the Croatian Ministry of Education. Reflecting on the purposes of PT for different groups of pupils, this official observed:

A small proportion of Croatian people, usually those who are most educated, see the purpose of education in terms of its value, investment in the future, international mobility ... In my opinion, the number of these individuals is very small. (High official from the Ministry of Science, Education and Sports, Croatia)

The notion that PT is an enrichment strategy for only a limited number of families is consistent with the quantitative results from the initial PT study. As in that project, interview data overwhelmingly suggests that the use of PT services is most frequently related to passing exams, completing the grade and fulfilling requirements set by teachers, even for pupils from more privileged backgrounds. The strategic approach towards PT use, described in the above quotes, is 
suggestive of the ability of privileged families to prevent educational problems in the first place or to efficiently and effectively address problems when they first appear. The results of both scenarios are enhanced opportunities for educational success and a reduction in the chance for educational failure of children from privileged backgrounds.

Data also indicate that, for many of these families, PT is often used as a tool for structuring children's out of school time:

I do not see anything wrong in it. At least I know where he is and what he's doing. After all, it is learning and any learning is good in my opinion. (Parent, B\&H)

Apart from time structuring, PT lessons also serve a much more complex purpose of compensation for activities that might otherwise have been undertaken within the family. This is evidenced in the words of a Croatian Member of Parliament (MP):

I often think that parents, in order to help themselves and even control the learning and achievement of their children, are more willing to pay and send them to private lessons. I know it from my own personal situation, where my daughter and son-in-law are competent in Maths, but they think sending their son to PT is an easier way. He does not listen to them. It is just simpler. (MP, Croatia)

Several insightful elements stand out in this quote. First, it is clear that the use of PT seeks to control the learning activities of the pupil. However, distinctive to this situation is the fact that parents opt to hire a tutor despite being competent to help their child themselves. Arguably, the reason for this could be assigned to a lack of successful communication within the family, pointing towards more general problems within families in both societies. This sentiment is even more concretely illustrated in the words of the director of a Croatian assessment centre, speaking of a time when he served as a private tutor:

I was providing lessons for children who were sent by their parents just because someone was supposed to sit beside them. They were cognitively capable of mastering all tasks, but needed someone as a watchdog. This was supposed to be their parents but they were either too busy or communication between them was lost. I was basically hired to sit beside them. (Director of assessment centre, Croatia)

In Bosnia \& Herzegovina, the notion that PT use was becoming a status symbol for certain groups of families emerged amongst interviewees, a finding not present in the Croatian data. This sentiment was evident in the words of an MP dealing with education issues:

For a particular category of people, whose income is quite above average, PT is becoming a matter of prestige, a measure of how much they care about their children. A true status symbol. (MP, B\&H) 
Arguably, this quote suggests that reliance on PT services is not only being used as a means to gain educational success but also to visibly emphasise and construct social status. The fact that this appeared only in the Bosnian case suggests that this might be a process occurring in societies characterised by increased social inequalities.

In general, most of the presented excerpts emphasise the responsibility of parents for pupils' use of PT, with some statements coming close to placing direct blame for extensive PT use on parents. Perhaps not surprisingly, a contrasting opinion emerged in focus groups with parents in both countries, where parents expressed a view in which characteristics of the educational system and the work of teachers were most responsible for the omnipresence of PT. This inherent complexity of the PT phenomenon was perhaps most clearly revealed in the discrepant perspectives of educational stakeholders speaking from both personal and professional positions, as evidenced by the following interview excerpt:

I am strongly opposed to private tutoring, both as a teacher and a union leader. However, when it came to my child ... you know, I was convinced that she will not need it, but when it came to the point that I even thought that something I am not willing to do may contribute to her not achieving success, I backed down. I thought her failure would be my failure. I was in a position to afford the tutoring for her and I did it. I still think it is an extremely negative thing for the system, but can be positive for the individual. (Representative of the Teachers' Union, Croatia)

While earlier quotes suggested that PT use is an accessible and easy decision for families from more advantaged socio-economic backgrounds, the use of PT represents a significant sacrifice for lower-income families, as evidenced by the words of PT provider:

I literally had a case of a father going to a loan shark to borrow money to pay for tutoring in Chemistry. Keep in mind the amount he needs to pay. His daughter had problems and he paid for tutoring to get her to the level to pass (Individual PT provider, Croatia)

Although the last part of this quote points towards the promotion of the provided services, the core of the statement is a salient depiction of the hardship placed on some families for securing the funds for financing PT. This position was also confirmed in the words of a parent from Bosnia \& Herzegovina. Speaking about a single mother of two children studying in her child's class, a parent reported:

We have two children of a single parent in our class. She has very low income but pays for private lessons. She wants them to succeed and would do anything in order to achieve that. (Parent, B\&H)

Although both quotes are third party testimonies constructing the motivation of parents from underprivileged families, they illustrate the determination of parents to provide this service to their own children in addition while also depicting the hardship lower income families face in financing PT services. For these families, 
continuous tutoring support often seems out of their financial reach, as evidenced by the words of one parent from Bosnia \& Herzegovina:

I know she would benefit from more continuous use of private lessons, but times are such that I cannot afford that. (Parent, B\&H)

In most cases, families use services as a means of securing the continuation of education in a situation where a child has failing grades or problems in school. A teacher and PT provider from Croatia stated:

You have those parents who don't have much money and monitor children

less. These go together sometimes, and they often come when push comes to shove: a few weeks before the end of the year. (PT provider, Croatia)

Although somewhat patronising, these words capture the general pattern of use for underprivileged families. In comparison to families from privileged backgrounds, these excerpts depict less strategic use of PT in which it is almost never used for the purposes of educational enhancement. Arguably, this less strategic and continuous use of PTI is also related to the financial situation of families.

The findings also suggest that the accessibility and affordability of PT services are not the only issues contributing to social inequity. Perhaps even more important are issues surrounding patterns of use and the quality of PT service, as well as the function and assigned importance of the service for families that rely on PT. In fact, interview data suggests that these aspects raise important concerns over social inequities related to PT in both Bosnia \& Herzegovina and Croatia.

\section{Social Equity and PT - An Issue of Marginal Importance for Educational Stakeholders}

None of the interviewees in either country spontaneously related the issue of social equity with the use of PT. However, when specifically probed about this issue, almost all interviewees acknowledged that the previously mentioned differences in the quantity, quality and purpose of services between different social groups can and are producing educational and social inequalities. This acknowledgement is evidenced by the response from a high official from the Ministry of Education in Bosnia \& Herzegovina:

PT is strengthening existing social inequality, so it can be assumed that those who can afford PT in the end have better education from those who cannot afford it. Their only option is formal education which, unfortunately, does not have the necessary quality. (High official from the Ministry of Education, $\mathrm{B} \& \mathrm{H})$

This policy maker's frank statement indicates an understanding of the relationship between social equity and PT, but more importantly it highlights the implications of this relationship for the individual pupil. Surprisingly, it also contains somewhat harsh judgment on the quality of the education system for which the respondent is responsible. Finally, the use of words such as 'only option' and 'unfortunately' is 
indicative of an emotional position towards both mainstream education and the families who solely rely on its services. However, although this respondent expresses an awareness of the relationship between social equity and PT, there is little to suggest a concern for the larger implications of the situation described. In fact, the analyses of the statements from other interviewees generally suggested that the position of interviewees towards issues of social equity was shaded by elements of political correctness. Specifically, while most respondents expressed an attitude that any process increasing inequality should be perceived as negative, there was little evidence for any in-depth concern over social inequities. Ultimately, it seems that social equity issues associated with PT emerged as being of marginal importance in the views of stakeholders.

In addition to recognising the shortcomings of the mainstream system, some interviewees expressed the potentially problematic position that pupils from underprivileged settings are expected to make bigger efforts in order to achieve educational success, while those from privileged familial backgrounds would supplement their inefficiencies by purchasing PT services. This perspective was voiced repeatedly in many interviews in both settings:

Those who have less perhaps appreciate education more; they fight more, aware that the only way to change something is with the knowledge gained. Those who have, they pay. (Political party representative dealing with education issues, $\mathrm{B} \& \mathrm{H}$ )

On the whole, these perspectives depict a sentiment that, while all members of society will be able to fulfil their aspirations, those from privileged classes will do so through PT and those from underprivileged groups through additional individual effort and struggle. These rationalisations were particularly evident in the views of policy makers, a finding that might arguably be interpreted as a form of justification of their own positions and (in)actions.

\section{Educational Policy - Impaired and Nostalgic}

In both countries, the lack of sensitivity and priority attached to the issue of social equity amongst the interviewees is further reflected by an impression of limited willingness and readiness to devise policy options that address social inequity in education. This is clearly evident in the frank and self-critical reflection of a high official from the Croatian Ministry of Education.

It is an important issue for educational policy, which covers all of its shortcomings and failures with silence and a lack of reaction. I know it may sound strange [given my position at the Ministry] but that is how it is. By not doing anything, we are not trying to equalise the conditions of education and thus contribute to the implicit discrimination. (High official from Ministry of Science, Education and Sports, Croatia) 
This statement illustrates an overall lack of ambition to ameliorate the formal education system. It further reflects the low potential for the development and implementation of policies that would lead to more equity in education. Most significantly, the excerpt is indicative of a worrying acceptance of the current state and the helplessness of those in power to address it. The declaratory, almost defeatist, stance is further evident in the words of the MP from Croatia:

The educational system reproduces the social stratification of Croatia and for me that is contradictory to the ideal of the social state. The least this country can do is to give an opportunity to those currently not privileged to excel in the next generation. This is a hard task and we are not doing anything in order to do achieve this. (Member of the Parliament, Croatia)

Furthermore, numerous interviewees, regardless of their political background, articulated a sense of decreasing social equity as a result of the economic and social transition experienced by both countries along with a lack of competence to address the situation:

The time of social equity has passed and we need to learn how to live with that. (Pedagogical Institute, B\&H)

Or in the case of Croatia:

Somewhere along the line in the last 20 years we have become a society and educational system that does not value or foster equal opportunities and equality. I do not know where we lost that. (High official from the teachers' unions, Croatia)

These quotes are illustrative of another connection often observed in the responses of stakeholders, in which the idea that inequality has become a very visible and palpable part of peoples' lives and that educational services have become a marketable good was related to an overall sentiment of a general decline in societal cohesion. In general, interviews revealed a strong sense that the previous system of education was less influenced by the power of financial assets. Indeed, it seems that the above quotes indicate a general sentiment of nostalgia in which education was more equitable and was viewed as a tool for social mobility, even for those from underprivileged backgrounds. In light of this and the overall recognition of the relevance of social equity in education, the lack of action and feelings of incapability and unwillingness to adapt and change to new circumstances amongst educational stakeholders seems even more contradictory and surprising. Instead, it seems that PT providers were those most prepared for a transitional change in the education system, as one of them aptly explained:

You cannot enter capitalism and then expect that education will be left out of it. People here just don't want to accept the reality we are in. (PT provider, Croatia) 


\section{CONCLUSIONS}

The findings presented in this paper confirm the position of PT as an allencompassing phenomenon in both Croatia and Bosnia \& Herzegovina. Given the increased affordability of the service due to diversified supply, even pupils from lower socio-economic backgrounds are able to afford some form of PT. The findings further suggest that the issue of social equity in both countries is more specifically related to differences in the patterns and purpose of PT use for groups of pupils from different socio-economic backgrounds, rather than on a measure of attendance alone. Pupils from more privileged settings rely on PT more continuously and strategically and are in a position to hire tutors of higher quality. Together, these findings point towards a somewhat subtler and potentially more consequential effect of PT on issues of social equity: pupils from more privileged families are in an increasingly more advantageous position to use PT in order to more promptly and effectively reduce the chances of educational failure. The responses from stakeholders further suggest that families of more advantaged economic backgrounds use PT in order to structure their children's out of school time and control their learning. In contrast, stakeholders' views suggest that underprivileged families use PT only in critical moments, when educational failure is imminent. There is also evidence that privileged families use PT in order to compensate for some of the activities that should have otherwise been undertaken within the family but are not due to poor communication or other problems within the family. However, this sentiment was strongly rejected in the responses of parents who participated in the research.

Despite differing economic and social situations in the two countries over the last two decades, there is strong evidence for an overall convergence in relation to the PT phenomenon. The exception to this is the use of PT as a status symbol in Bosnia \& Herzegovina. This convergence may be a result of the shared values and cultural patterns in both countries, as well as the lack of any substantial change within both systems of education.

On the whole, the findings presented indicate a sense of urgency for the development of educational policies that address issues of social equity related to PT. However, the analyses of educational stakeholders' perspectives in both countries suggest that the issue of social equity related to PT is of marginal concern. In both countries, the frank discourse of state officials suggests a somewhat peculiar position in which those in power are aware of the lack of quality and inefficiencies of the system but are impaired, reluctant or incompetent to address them. Similarly, with the exception of PT providers, all interviewees expressed personal opposition to the observed increase in social and educational inequalities. They further expressed a form of nostalgia for the egalitarian values of the former political system. Notwithstanding, they were unwilling to proactively address these increasing inequalities. Arguably, it seems that authorities in both settings must still come to terms with the realities that emerged over two decades. Clearly, they are not yet ready to actively deal with the effects of the transition to market economies on the educational system. These notso-new realities demand proactive educational policies. Yet, the latter appear quite 
improbable in light of the above described position of state officials. In all likelihood, both countries will experience further growth in PT use, increased differences in the quality of PT for pupils from different socio-economic backgrounds and, ultimately, increased social and educational inequality. Arguably, this increase in social and educational inequality in this context has a real potential of re-igniting tensions between and across social, economic and ethnic groups in the fragile political and social situation in which both countries found themselves after the conflict, and in the midst of the transition from planned to market economies.

\section{APPENDIX}

\section{List of Selected Interviewees}

\begin{tabular}{|c|c|c|}
\hline Educational stakeholders & Bosnia \& Herzegovina & Croatia \\
\hline $\begin{array}{l}\text { Higher officials from the } \\
\text { Ministry of Education }\end{array}$ & \multirow{2}{*}{$\begin{array}{l}6 \text { interviews with higher } \\
\text { officials/ advisors in Federal } \\
\text { and Cantonal Ministries of } \\
\text { Education }\end{array}$} & $\begin{array}{l}1 \text { interview with State secretary } \\
\text { for compulsory education }\end{array}$ \\
\hline $\begin{array}{l}\text { Higher officials from the } \\
\text { regional or local executive } \\
\text { government }\end{array}$ & & $\begin{array}{l}\text { Paired interview with higher } \\
\text { officials from Zagreb } \\
\text { Educational Authority }\end{array}$ \\
\hline $\begin{array}{l}\text { Representatives of } \\
\text { parliamentary political parties } \\
\text { in charge of education }\end{array}$ & $\begin{array}{l}1 \text { paired interview with } \\
\text { representatives of the main } \\
\text { opposition party in Federation } \\
\text { of BiH / } 1 \text { interview with } \\
\text { representative of the main } \\
\text { opposition party in R. Srpska }\end{array}$ & $\begin{array}{l}2 \text { interviews with } \\
\text { representatives of the ruling } \\
\text { and main opposition party }\end{array}$ \\
\hline $\begin{array}{l}\text { Officials from the professional } \\
\text { organisations in the field of } \\
\text { education (e.g. Institute of } \\
\text { Education, Pedagogical } \\
\text { institutes, Curriculum } \\
\text { authorities, Inspectorates, ...) }\end{array}$ & $\begin{array}{l}4 \text { interviews with Directors or } \\
\text { Advisors in Pedagogical } \\
\text { Institutes/ Agency for } \\
\text { Preschool, Primary and } \\
\text { Secondary Education }\end{array}$ & $\begin{array}{l}6 \text { interviews with } \\
\text { representatives of: } \\
\text { 1. Education and Teacher } \\
\text { Training Agency (paired } \\
\text { interview) } \\
\text { 2. National Centre for External } \\
\text { Evaluation in Education } \\
\text { 3. Agency for Science and } \\
\text { Tertiary Education } \\
\text { 4. Committee for Introduction } \\
\text { of the State Matura in } \\
\text { Secondary Education } \\
\text { 5. Council for National } \\
\text { Curriculum ( } 2 \text { interviews) }\end{array}$ \\
\hline $\begin{array}{l}\text { Representatives from NGOs/ } \\
\text { Interest groups dealing with the } \\
\text { educational issues }\end{array}$ & $\begin{array}{l}2 \text { interviews with } \\
\text { representatives of Parents } \\
\text { Council/ Association }\end{array}$ & $\begin{array}{l}1 \text { paired interview with } \\
\text { representatives of National } \\
\text { Committee of Pupils }\end{array}$ \\
\hline $\begin{array}{l}\text { Representatives from the } \\
\text { teachers' unions }\end{array}$ & $\begin{array}{l}2 \text { interviews with } \\
\text { representatives from Teacher } \\
\text { Unions }\end{array}$ & $\begin{array}{l}2 \text { interviews with leaders of } \\
\text { Teacher Unions }\end{array}$ \\
\hline School principals & - & $\begin{array}{l}\text { Representative of the } \\
\text { Association of Croatian } \\
\text { Secondary School Principals }\end{array}$ \\
\hline $\begin{array}{l}\text { Elementary and secondary } \\
\text { school teachers }\end{array}$ & $\begin{array}{l}2 \text { focus groups with primary/ } \\
\text { secondary Maths teachers }\end{array}$ & $\begin{array}{l}1 \text { focus group with secondary } \\
\text { Maths teachers }\end{array}$ \\
\hline
\end{tabular}




\section{BORIS JOKIĆ, ANDREA SOLDO \& ZRINKA RISTIĆ DEDIĆ}

\begin{tabular}{|l|l|l|}
\hline $\begin{array}{l}\text { PT providers (organised } \\
\text { groups) }\end{array}$ & $\begin{array}{l}\text { 1 interview with organiser of } \\
\text { preparatory courses for } \\
\text { University entrance exams } \\
1 \text { interview with PT provider }\end{array}$ & $\begin{array}{l}\text { interviews with preparatory } \\
\text { courses organisers for } \\
\text { University entrance/State } \\
\text { Matura exams }\end{array}$ \\
\hline Parents & $\begin{array}{l}\text { 2 focus groups with parents of } \\
\text { pupils in primary/vocational } \\
\text { school }\end{array}$ & $\begin{array}{l}1 \text { focus group with parents of } \\
\text { pupils in gymnasium }\end{array}$ \\
\hline
\end{tabular}

\section{NOTES}

1 This paper is based on the findings from the Network of Education Policy Centres' (NEPC) comparative qualitative project entitled 'The Private Tutoring Phenomenon: Developing Policy Options', undertaken in Azerbaijan, Bosnia \& Herzegovina, Croatia, Estonia, Georgia, and Mongolia. The project investigated the holistic concept of PT as a phenomenon permeating all educational levels. It was envisaged as a continuation of the research project 'Monitoring of Private Tutoring', which explored the PT phenomenon in Eastern Europe and Central Asia (Silova, Būdienè, \& Bray, 2006). As in that project, the working definition of PT was: a 'fee-based instruction in academic school subjects that is complementary to instruction mainstream schools provide free of charge'. PT includes lessons provided on a one-on-one basis or in small groups by individual instructors. It also includes larger classes taught by individual and company-employed tutors (Silova, Būdienè, \& Bray, 2006, p. 13).

\section{REFERENCES}

Babarović, T., Burušić, J., \& Šakić, M. (2009). Prediction of educational achievements of primary school pupils in the Republic of Croatia, Social Research, 18 (4-5), 673-695 [in Croatian].

Baranović, B. (Ed.). (2006). National curriculum for compulsory education in Croatia - Various perspectives. Zagreb: Institute for Social Research [in Croatian].

Bray, M. (1999). The shadow education system: Private tutoring and its implications for planners. Paris: UNESCO International Institute for Educational Planning (IIEP).

Bray, M. (2003). Adverse effects of private supplementary tutoring: Dimensions, implications and government responses. Paris: UNESCO International Institute for Educational Planning (IIEP).

Bray, M. (2009). Confronting the shadow education system: What government policies for what private tutoring? Paris: UNESCO International Institute for Educational Planning (IIEP).

Bray, M. (2011). The challenge of shadow education: Private tutoring and its implications for policy makers in the European Union. Brussels: European Commission.

Gorard, S., \& Taylor, C. (2004). Combining methods in educational and social research. Maidenhead, England: Open University Press.

Gregurović, M., \& Kuti, S. (2010). Effect of socioeconomic status on students' educational achievement: The example of the PISA study, Croatia 2006. Journal of Social Policy, 17(2), 179196 [in Croatian].

Heyneman, S. P. (2000). From the party/state to multiethnic democracy: Education and social cohesion in Europe and Central Asia. Educational Evaluation and Policy Analysis, 22(2), 171-191.

Husremović, Dž. \& Trbić, Dž. (2006). Private tutoring in Bosnia and Herzegovina. In I. Silova, V. Būdienè, \& M. Bray (Eds.), Education in a hidden marketplace: Monitoring of private tutoring. New York: Open Society Institute.

Jokić, B., \& Ristić Dedić, Z. (2007). In the shadow: Private tutoring in Croatian education. Zagreb: Institute for Social Research [in Croatian].

Jokić, B., \& Ristić Dedić, Z. (2010). Differences in educational attainment of third and seventh Grade pupils in Croatia with respect to gender and parents' educational level: A population perspective. Journal of Social Policy, 17(3), 345-362 [in Croatian].

Jung, J. H., \& Lee, K. H. (2010). The determinants of private tutoring participation and attendant expenditures in Korea. Asia Pacific Education Review, 11(2), 159-168. 


\section{PRIVATE TUTORING AND EQUITY IN CROATIA AND BOSNIA \& HERZEGOVINA}

Jurčić, Lj., \& Vojnić, D. (2010). Quo vadis Croatia? Thirty year stagnation in the light of our newer economical history. Radical change in the economic policy and a model of development of Croatia on the path to European Union. Economic Review, 61(12), 793-851 [in Croatian].

Kim, J. (2007). The determinants of demand for private tutoring in South Korea. Seoul, Korea: Department of Education, Yonsei University, South Korea.

Klemenović, J., \& Milutinović, J. (2002). Experience of previous educational system reforms in our country - Part I, Pedagogy, 40(4), 51-73 [in Serbian].

Klemenović, J., \& Milutinović, J. (2003). Experience of previous educational system reforms in our country - Part II. Pedagogy, 41(1), 49-67 [in Serbian].

Kwok, P. (2004). Emergence of demand for private supplementary tutoring in Hong Kong: Argument, indicators and implications. Hong Kong Teachers' Centre Journal, 3, 1-14.

Ristić Dedić, Z., \& Jokić, B. (2011). Development of the policy options for the regulation of private tutoring phenomenon in Croatia - Research report. Zagreb: Institute for Social Research [in Croatian].

Ristić Dedić, Z., Jokić, B., \& Jurko, L. (2006). Private tutoring in Croatia. In I. Silova, V. Būdienè, \& M. Bray (Eds.), Education in a hidden marketplace: Monitoring of private tutoring. New York: Open Society Institute.

Scanlon, M., \& Buckingham, D. (2004). Home learning and the educational marketplace. Oxford Review of Education, 30(2), 287-303.

Schneider, S. (2006). Social inequality in education from a cross-national perspective - What do we know, and how can we explain? Paper presented at the European Consortium of Sociological Research (ECSR) Summer School "Integrating sociological theory and research in Europe (ISTARE) Quality and inequality in education: Theory, research, and policy". Prague, Czech Republic.

Silova, I. (2010). Private tutoring in Eastern Europe and Central Asia: Policy, choices and implications. Bethlehem, PA: College of Education, Lehigh University.

Silova, I., Būdienė, V., \& Bray, M. (Eds.). (2006). Education in a hidden marketplace: Monitoring of private tutoring. Overview and country reports. New York: Open Society Institute.

Silova, I., \& Bray, M. (2006). The hidden marketplace: private tutoring in former socialist countries. In I. Silova, V. Būdienè, \& M. Bray (Eds.), Education in a hidden marketplace: Monitoring of private tutoring. New York: Open Society Institute.

Soldo, A. (2011). The phenomenon of private tutoring in Bosnia and Herzegovina. Sarajevo: proMENTE Social Research.

UNDP (2009). Assessment of development results: Bosnia and Herzegovina. Sarajevo: United Nations Development Programme.

World Bank (2006). Croatia: Living standards assessment. Volume 1: Promoting social inclusion and regional equity. Report no. 37992. Washington, DC: The World Bank. 